\title{
Uma palavra sobre matéria: Bakhtin e Tynianov
}

\author{
Alastair Renfrew ${ }^{1}$ \\ Il y a pour toute chose une \\ théorie qui se proclame \\ elle-même 'le bon sens'. \\ Victor Hugo
}

Résumé: Cet article se penche sur questions de materialisme et de formalisme durant les années 1920-1930 dans le contexte soviétique. On analyse la querelle entre les sources de la pensée marxiste et des études formalistes pour reflechir surtout autour de la materialité des études literaires et aussi sur la dichotomie entre forme et contenu.

Mots-clé: Esthetique et Literature; Materialités Literaires; Formalisme; Contexte Sovietique

Resumo: Este artigo se debruça em torno de questões relacionadas ao materialismo e ao formalismo durante os anos 1920-1930 no contexto soviético. Buscamos analisar a querela entre as bases do pensamento marxista e dos estudos materialistas, a fim de refletir, sobretudo, em torno da materialidade dos estudos literários e também sobre a dicotomia entre forma e conteúdo. Palavras-Chave: Estética e Literatura; Materialidades Literárias; Formalismo; Contexto Soviético

Quando Mikhail Bakhtin escreveu, em 1924, a respeito dos perigos de uma "estética material"2, sua principal preocupação não era em relação à abordagem amplamente marxista com a qual o pensamento materialista é muito comumente associado no campo literário; o principal destinatário da polêmica de Bakhtin era, preferencialmente, o chamado "método formalista" e seus variados proponentes, os quais ofereciam a única alternativa significante para o "Marxismo" na luta por destaque nos estudos literários soviéticos. As motivações de Bakhtin ao atacar os Formalistas podem ter sido, em parte, pragmáticas, assim como também ocorreu com Pavel Medvedev, em grande parte, em sua declaração escrita mais

1 Professor Leitor de língua Russa na Universidade de Durham. O artigo foi publicado originalmente em língua Inglesa em 'The Slavonic and East European Review', 84.3, 2006, p.419-445.

2 M. M. Bakhtin, 'Problema soderzhaniia, materiala i formy v slovesnom khudozhestvennom tvorchestve', in Raboty 1920-kh godov, Kiev, 1994, pp. 257-318; 'The Problem of Content, Material and Form in Verbal Art', in Art and Answerability: Early Philosophical Essays by M. M. Bakhtin, ed. Michael Holquist and Vadim Liapunov; trans. Vadim Liapunov and Kenneth Brostrom, Austin, TX, 1990, p. $257-325$ (hereafter, Bakhtin, 'The Problem of Content, Material and Form'; traduções modificadas, as referências de página são da edição russa lançada primeiro).O artigo foi parcialmente publicado como 'K estetike slova', em Kontekst-73, Moscou, 1974, pp. 258-80, e publicado por completo no ano seguinte em M. M. Bakhtin, Voprosy literatury i estetiki: issledovaniia raznykh let, ed. S. Leibovich, Moscow, 1975, p. 6-71. Para uma visão completa, por vezes tendenciosa do contexto e das circunstâncias da não-publicação do artigo em 1924, ler o comentário em M. M. Bakhtin, Sobranie sochinenii, vol. 1, ed. S. G. Bocharov and N. I. Nikolaev, Moscow, 2003, p. 707-41 
tarde contra o formalismo, O método formal nos estudos literários, publicada em 1928, quando o produto de sua luta era menos aberto à discussão ${ }^{3}$; e eles também podem ter envolvido um certo hauteur ${ }^{4}$, com a implicação de que as abordagens grosseiramente deterministas que passaram pelos estudos marxistas representados, em um nível teórico, constituíam um oponente impróprio.

O elemento mais importante da motivação de Bakhtin, no entanto, é a convicção de que o Formalismo e o Marxismo, ao invés de serem os inimigos naturais, como os seus engajamentos na luta poderiam sugerir - uma presunção que foi posteriormente intrincada pela história literária canônica - na verdade, ambos representariam dois lados da mesma moeda. ${ }^{5}$

Dois problemas teóricos fundamentalmente relacionados recaem no cerne desta convicção: o primeiro é a dicotomia entre forma e conteúdo, e o segundo, vinculado ao primeiro, é tão inconveniente quanto é negligenciado - o que é, de fato, a materialidade da literatura?

No período entre a dissolução do Lef e sua eventual 'capitulação' dos representantes ostensivos do marxismo no estudo literário, Viktor Shklovskii fez uma última tentativa de reunir as forças dispersas do Opoiaz ${ }^{6}$. O objetivo de Shklovskii pode ter sido a segurança organizacional mais do que a restauração de uma unidade teórica perdida, mas ele foi encorajado nas suas tentativas - ou pelo menos considerado - por Roman Jakobson e Iurii Tynianov, cujo conteúdo programático em 1928, "Problema no estudo da Literatura e da Linguagem", viria a ser o foco teórico e organizacional da restauração do Opoiaz ${ }^{7}$.

3 P. N. Medvedev, Formal'nyi metod v literaturovedenii. Kriticheskoe vvedenie v sotsiologicheskuiu poetiku, Leningrad, 1928; P. N. Medvedev/M. M. Bakhtin, The Formal Method in Literary Scholarship: A Critical Introduction to Sociological Poetics, trans. Albert J. Wehrle, Baltimore, MD, 1978. Esta tradução foi reimpressa em 1985 com os nomes dos autores em ordem reversa: M. M. Bakhtin/P. N. Medvedev, The Formal Method in Literary Scholarship: A Critical Introduction to Sociological Poetics, trans. Albert J. Wehrle, Cambridge, MA, 1985 (hereafter, Medvedev, The Formal Method; todas as citações em Inglês são da edição mais nova).

4 Eminência. NT.

5 É importante ressaltar, entretanto, que Bakhtin às vezes é visto como um estudioso operando entre o Formalismo e o Marxismo: ver por exemplo Ann Shukman, 'Between Marxism and Formalism: the Stylistics of Mikhail Bakhtin', in Elinor Shaffer (ed.), Comparative Criticism: A Yearbook, 2, 1980, p. 221-34; Michael Bernard-Donals, Mikhail Bakhtin: Between Phenomenology and Marxism, Cambridge, 1994.Galin Tihanov, em uma avaliação mais ampla do espaço do Formalismo na história intelectual do Ocidente, expressou sua curiosa relação ‘dupla' com o Marxismo ao tentar 'ser mais Positivista do que o Positivismo' e a tentativa de competir com o Marxismo na mesma arena (conceitual e pragmática): Galin Tihanov, 'Zametki o dispute formalistov $i$ marksistov 1927 goda', Novoe literaturnoe obozrenie, 50, 2001, p. 279-86; see also D. Ustinov, 'Materialy disputa “Marksizm i formal'nyi metod” 6 marta 1927 g.', Novoe literaturnoe obozrenie, 50, 2001, pp. 247-78.

6 Opoiaz [Obshchestvo izucheniia teorii poeticheskogo iazyka] deixou de funcionar como um grupo formal desde o momento da partida forçada de Shklovskii para Berlim no início de 1922, embora Boris Eikhenbaum e Iurii Tynianov permanecessem vinculados pessoalmente e profissionalmente muito após esta data. Logo após seu retorno à Rússia no fim de 1923, Shklovskii pediu ajuda institucional no contexto mais utilitário, e talvez, politicamente promissor da aliança Marxista/Futurista Lef [Levyi front iskusstva], que absorveu o ex-membro da Opoiaz,, Osip Brik, e pôde ostentar em sua essência a figura emblemática de Vladmir Maiakovskii.Lef, por sua vez, se desfez no outono de 1928 devido a tensões ideológicas e pessoais, cuja combinação precisa é difícil de determinar.

7 Shklovskii convidou vários estudantes de diversos níveis de proximidade ao Opoiaz para responder à tese baseada no artigo de Tynianov e Jakobson como base para uma forma de manifesto publicado para a nova organização; dessa maneira, é irônica a forma como a tentativa culminou na publicação da resposta individual de Shklovskii, como a tese profundamente ambivalente e/ou comprometida 'Pamiatnik nauchnoi oshibke', que foi interpretada como encarnando uma capitulação sem reservas/tendenciosa, e tática. V. B. Shklovskii, 'Pamiatnik nauchnoi oshibke', Literaturnaia gazeta, 27 January 1930, p. 4. Also, Iurii Tynianov and Roman Jakobson, 'Problemy izucheniia literatury i iazyka' [1928], in Tynianov, Poetika. Istoriia literatury. Kino, Moscow, 1977 (hereafter, Poetika), pp. 282-83; 'Problems in the Study of Literature and Language', in Ladislav Matejka and Krystyna Pomorska (eds), Readings in Russian Poetics: Formalist and Structuralist Views, Ann Arbor, MI, 1978 [1971], pp. 79-81.Para um estudo detalhado e recente dos esforços de Shklovskii 
Shklovskii também deve ter sido encorajado, entretanto, por algo muito mais indefinido, ou seja, sua avaliação em relação ao fracasso contínuo das críticas marxistas dispostas a ocupar o centro do debate da crítica literária com algum nível de convicção teórica. De acordo com o que Shklovskii escreveu a Osip Brik em Fevereiro de 1929:

A questão mais difícil é a questão das nossas relações com os Marxistas. Isto é, em sua essência, uma questão de uma atitude em resposta a uma atitude, porque os próprios Marxistas não foram encontrados (Ibid., p. 142). ${ }^{8}$

Esta declaração até representa um epitáfio da série de tentativas para construir uma teoria marxista da Literatura durante a primeira década soviética: "Marxistas não foram encontrados".

O diagnóstico de Shklovskii da falta de abordagens convincentemente marxistas para a literatura não é tão surpreendente quanto pode parecer, principalmente porque os fundamentos sob os quais a estética marxista foi construída foram produzidos de modo profundamente problemático.

Há duas principais razões para isso, as quais são tão fortemente relacionadas que podem ser consideradas virtualmente inseparáveis: a primeira diz respeito à relativa reticência de Marx em relação às questões estritamente estéticas (expressão que pode ter parecido para ele, em termos, uma contradição) ${ }^{9}$; a segunda é a necessidade concomitante desta deficiência ser complementada por seguidores e intérpretes de Marx no contexto russo e soviético, frequentemente, e mais danosamente, com referência direta aos princípios centrais do marxismo que foram somente secundariamente, ou até tangencialmente, preocupados com a estética ${ }^{10}$. Deste modo, para dar um exemplo óbvio, as leis da oferta e da procura

a este respeito, ver Aleksandr Galushkin, "I tak, stavshi na kostiakh, budem trubit' sbor": K istorii ne sostoiavshegosia vozrozhdeniia Opoiaza v 1928-1930 gg.', Novoe literaturnoe obozrenie, 44, 2000, pp. 136-58.

8 Shklovskii prossegue na mesma carta para relacionar a insistência de Lev Iakubinskii para com a necessidade de uma linguística marxista, apesar da incerteza deste com relação ao que precisamente isso poderia implicar. A linguística nos oferece um paralelo educativo para os estudos literários a esse respeito, e eu estou devendo a Nikolai Nikolaev por destacar um aspecto da 'lógica' particular do objetivo de Shklovskii: Se o Marxismo foi capaz de estabelecer-se como uma doutrina linguística 'Marxista' autorizada, porque não uma marca do Formalismo modificado (ex. historicizado ou sociologizado) como 'o método' para a crítica literária?

9 Esta dificuldade é agravada pela publicação histórica de certa obra de Marx em tradução russa: A Ideologia Alemã, por exemplo, foi publicada primeiramente em 1932, muito depois do momento onde poderia afetar o debate corrente na teoria e crítica. Para um trecho maior, ver Karl Marx, Selected Writings, ed. David McLellan, Oxford, 1977, pp.159-91. Com o benefício de uma visão retrospectiva, o capítulo (section) sobre "As Primeiras Premissas do Método Materialista" de A ideologia alemã parece quase profetizar a crítica de Voloshinov a respeito da ideia de Plekhanov de "psicologia social", e, particularmente, de sua definição de materialidade do signo, cuja afirmação de Marx foi “inicialmente 'espírito' que está aflito [...] com a maldição de ser 'oprimido/sobrecarregado' com a matéria, que aqui faz sua aparição na forma de camadas agitadas de ar, sons, ou seja, da língua,' é um 'antepassado' paradoxal. (Marx, Selected Writings, p. 167). Ver V. N. Voloshinov, Marksizm i filosofiia iazyka, in Voloshinov, Filosofiia i sotsiologiia gumanitarnykh nauk, St Petersburg, 1995, p. 216-380,(Continuação) (pp. 221-28); Marxism and the Philosophy of Language, trans. Ladislav Matejka and I. R. Titunik, Cambridge, MA, and London, 1986, pp. 9-15 (hereafter, Voloshinov, Marxism and the Philosophy of Language).

10 O principal autor entre estes é Plekhanov, o qual forneceu o pano de fundo estético do Marxismo da URSS dos anos 1920, e foi particularmente influente em sua ideia de 'psicologia social' como mediadora entre a base e a superestrutura; ver G. V. Plekhanov, psychology' as a mediator between base and superstructure; ver G. V. Plekhanov, Literatura i estetika, Moscow, 1958. Literatura i revoliutsiia, Lev Trotskii, Moscow, 1991 [1923] (Literature and Revolution, London, 1991) foi uma continuação importante e polêmica da suplementação estética de Marx, um refinamento na teoria de Plekhanov e Trotski; reconhecida com pouca frequência é a obra de Nikolai Bukharin 'O formal'nom metode v iskusstve', Krasnaia nov', 3, 1925, pp. 248-57, uma gravação estenográfica de sua contribuição à disputa 'Iskusstvo i revoliutsiia', que ocorreu em 13 de Março de 1925. 


\section{Conexão Letras}

podem ser invocadas na avaliação da produção e da circulação de "mercadorias" literárias, uma abordagem que encontrou expressão na obra de Boris Arvatov, ${ }^{11}$ em detrimento de um tratamento mais sofisticado em diferentes pontos da obra de Trotskii Literatura e Revolução. Trotskii tenta relacionar a estética da investigação ao cânone da teoria marxista e, ao mesmo tempo, antecipar e evitar as tentativas inaceitavelmente grosseiras e auto-destrutivas de outros autores tentarem fazer algo similar:

"Que a demanda pela arte não seja criada por condições econômicas é inargumentável. Mas nem a demanda pela alimentação ou pelo aquecimento é criada pela esfera econômica. Ao contrário, a economia é criada pela demanda de alimentação e aquecimento[...]. Os trabalhos artísticos devem, em primeiro lugar, ser julgados por suas próprias leis, isto é, por leis do campo da arte. Mas somente o marxismo é capaz de explicar porque e de onde uma determinada direção artística desponta em uma dada época, ou seja, quem demandou certas formas artísticas ao invés de outras e por quais razões. "I2

A suplementação da estética marxista pela referência de restrições não-estéticas não foi, entretanto, restrita à questão de oferta e procura, a qual poderia ser considerada como uma manifestação superficial de um problema mais basilar: a relação da 'base' (econômica) com a 'superestrutura' (ideológica).

As dificuldades implícitas pela pedra fundamental do materialismo dialético podem ser sintetizadas em uma única palavra que assombra as abordagens marxistas e materialistas da arte dentro e além do contexto soviético: o determinismo.

Se a diversidade de atividades humanas que combinadas formam a "cultura" são fenômenos da superestrutura que se desenvolve a partir da base econômica, a questão surge acerca da natureza precisa da relação entre a cultura, ou qualquer elemento desta e as relações econômicas que a alicerçam. A resposta que observa que as características da base determinam a natureza dos elementos superestruturais leva muito facilmente à presunção de uma causalidade direta, mecanicista: usando o exemplo dado por Valentin Voloshinov como algo parecido com uma ‘falácia do espantalho’ em sua discussão contra a viabilidade de tais interpretações mecanisticamente causais da relação base-superestrutura, a emergência do lishnii chelovek na ficção russa na metade do século 19 pode ter sido diretamente e intimamente relacionada a uma crise na autocracia e na economia parcialmente feudal do período imediatamente anterior ${ }^{13}$. A resposta de Voloshinov é argumentar que

O estabelecimento de uma conexão entre a base e um fenômeno isolado, abstraído de seu contexto ideológico integral e unificado, não possui nenhum valor cognitivo de fato. (Ibid., p. 229; pp. 17-18)

Voloshinov segue muito rigorosamente o argumento de Bukharin, embora, como veremos a seguir, com um propósito muito diferente:

Você pode isolar qualquer fenômeno da vida social, quaisquer fragmentos ou séries, mas [...] se você não vir sua função na vida, se você não considerá-lo como

11 B. Arvatov, 'Literatura i byt', Zvezda, 6, 1925, pp. 308-19; B. Arvatov, 'Utilitarizm v literature', Oktiabr', 12, 1925, pp. 100-06.

12 Trotskii, Literature and Revolution, p. 141-42; p. 207.

13 Voloshinov, Marxism and the Philosophy of Language, p. 230; p. 18. 
um componente orgânico de um todo social, [...] você jamais compreenderá estes fenômenos. (Bukharin, 'O formal'nom metode v iskusstve', p. 255)

Bukharin argumenta essencialmente que o modelo base-superestrutura requer um alto nível de sofisticação em sua aplicação nos fenômenos culturais e ideológicos, que consiste, mais ou menos, na recusa em executar o tipo de isolamento específico que Voloshinov mais tarde crItica: a crise política e econômica do início do século dezenove determina intimamente a aparição do lishnii chelovek.$^{14}$ Ainda, tão conclusivo quanto o mais primário dos deterministas, para os quais (juntamente com os arqui-anti-deterministas do início do Formalismo) suas críticas são voltadas a Bukharin, de como ele deixa intacto o paradigma de base-superestrutura, que é a base para uma dicotomia que se provou problemática e muitas vezes intransponível para a maioria das metodologias críticas: forma versus conteúdo.

A teoria da causalidade, seja mecanicista ou não, está inclinada a ser resistente à consideração da forma, porque a forma é imaterial para a ideologia: por que importa, para continuar com o nosso exemplo, se lishnii chelovek deve ser representado principalmente pela ficção, ou em versos ou ambos? Estímulos econômicos e sociais semelhantes para aqueles que "produziram" o lishnii chelovek encontraram sua expressão, em um nível temático, em quaisquer formas literárias que eram dominantes naquele período; os meios formais são receptivos aos efeitos ideológicos produzidos pelas mudanças nas relações econômicas de base, mas eles têm menos força para "determiná-los". E até mesmo quando o marxismo volta-se para questões de forma, há uma tendência de tratá-lo exatamente como conteúdo: a questão de quais formas particulares são "demandadas", segundo Trotskii, pela classe dominante está relacionada a fatores de base que têm determinado a dominância desta classe, ou que estão no processo de mudança da relação de classe. A forma pode obedecer o conteúdo, ou seja, eles se mantém em uma relação particular e hierárquica; ou, de algum modo bizarro, a forma é o 'mesmo' que o conteúdo, o que implica uma deformação ainda maior de sua relação.

A possibilidade de uma relação integral, mutuamente constitutiva é evitada desde o princípio por aderência, em qualquer nível, ao modelo base-superestrutura.

Por outro lado, o estímulo para os argumentos de Trotskii, Bukharin e, de um modo diferente para Voloshinov, é o comprometimento carregado de polêmica e agressividade da forma sobre o conteúdo, que, além da ideia de distinção de uma linguagem especificamente "poética", foi o próprio marco do nascimento do Formalismo.

A marca icônica do formalismo, repleta do pathos do futurismo, encontrou a sua expressão mais substancial nos trabalhos feitos por Shklovskii como "Kak sdelan 'Don Kikhot" "[Dom Quixote] ${ }^{15}$ e Khod Konia, a última sendo objeto específico do desdém de Trotskii em Literatura e Revolução $o^{16}$. Como Medvedev discutirá algum tempo mais tarde, a rejeição de Shklovskii à dialética do modelo de base-superestrutura que implica não só a predominância da forma em detrimento do conteúdo, mas também uma compreensão de que o conteúdo, e consequentemente o significado, é finalmente expulso, se não da própria obra literária em si, pelo menos do processo de seu estudo.

14 NT. A expressão lishnii chelovek significa 'homem supérfluo. Em 'Marxismo e Filosofia da Linguagem' Bakhtin/Volochinov fazem referência a esta representação do homem supérfluo no romance.

15 NT. As expressões acima foram traduzidas para a língua Portuguesa a fim de facilitar o entendimento do leitor. 16 V. B. Shklovskii, 'Kak sdelan "Don Kikhot”' [1921], in Shklovskii, O teorii prozy, Moscow, 1929, p. 91-124; 'The Making of Don Quixote', in Shklovsky, Theory of Prose, trans. Benjamin Sher, Elmwood Park, 1990, pp. 72-100. Viktor Shklovskii, Khod Konia, Orange, CT and Dusseldorf, 1986 [1923]. 
Esta expulsão do conteúdo consiste em duas operações relacionadas: Primeiro o "material" do trabalho literário é associado à fábula; o alcance/extensão de fenômenos éticos, políticos, históricos e eventos "da vida real" que, de diversas formas a precedem; eles são artisticamente organizados para formar seu siuzhet, às vezes referido como 'plot/roteiro', mas melhor compreendido como a organização literária imanente de eventos e fenômenos que constituem a fábula, transformada em diversos processos que poderiam tornar-se o foco técnico da teoria Formalista. A produção literária, nesta análise, é literalmente "feita de" elementos discrepantes de seu ambiente pré-literário, concebido no sentido mais amplo possível, e é trabalho do estudo literário determinar precisamente como este processo se desenrola. ${ }^{17}$

Secundariamente, a relação hierárquica atribuída ao artifício literário e ao material "real" na escola marxista soviética dos primórdios se reverte ${ }^{18}$ : a obra literária não é mais o "receptáculo" da materialidade ideológica significante, mas sim a sua matéria serve, em uma formulação celebrada, 'apenas como motivação dos instrumentos narrativos' 19 .

Sendo assim, o 'conteúdo’ da obra literária não tem significado por si próprio, mas sim como a forma pela qual é possível diversas técnicas de transformação e especificamente vários instrumentos de composição ['frenagem'] tormozhenie], 'dificultando'20 [zatrudnenie] a 'repetição' [povtorenie], etc.; todos esses elementos são relacionados ao instrumento 'mestre' da 'alienação' ou ao 'estranhamento' [ostranenie]). Por consequência, a contenção hiperbólica de Shklovskii de que as viagens de Don Quixote somente se tornaram significativas na medida que motivaram o instrumento de "agrupamento" [nanizyvanie], enquanto disponibilizaram a "matéria prima" para a construção de uma 'realidade' unicamente literária ${ }^{21}$.

O objetivo de Shklovskii é claro: enfraquecer uma ideia de representação realista "fiel" e, consequentemente, concepções deterministas da relação entre arte e vida (ou, como já vimos, entre base e superestrutura). Contudo, embora este passo caracteristicamente extremo possa ser considerado superdeterminado retoricamente, em oposição a teoricamente 'sincero', ele ilustra vivamente o abismo enorme entre os Formalistas e os Marxistas neste estágio inicial, e suas implicações teoricamente desastrosas para o problema da forma e do conteúdo.

Uma alternativa metodológica surgiu nos anos 1920, a qual prometia aperfeiçoar os piores defeitos do determinismo marxista e da abstração formalista. Esta tomou a forma de uma metodologia crítica 'cambaleante', que poderia desempenhar uma análise textual imanente da obra literária antes de examinar suas relações com o ambiente extra-artistico social' ao redor ('vnekhudoz-hestvennaia sotsial'naia sreda'). Voloshinov atribui esta abordagem em sua forma madura a Pavel Sakulin, embora existam inúmeros exemplos anteriores de uma orientação metodológica similar, incluindo Aleksandr Tseitlin e, mais uma vez, Literatura e Revolução de Trotskii. ${ }^{22}$

17 Tynianov consegue fazer uma declaração admiravelmente clara deste princípio em um artigo dedicado ao problema do siuzhet e fabula no cinema bem como no texto literário, mas sem ser desviado pela especificidade do material cinematográfico, que merece uma análise mais aprofundada em seu pleno direito: Iu. N. Tynianov, 'O siuzhete i fabule v kino' [1926], in Tynianov, Poetika. Istoriia literatury. Kino, pp. 324-25.Ver também Iu. N. Tynianov, 'Ob osnovakh kino' [1927], in ibid, pp. 326-45; Yury Tynianov, 'The Fundamentals of Cinema', Russian Poetics in Translation, 9, 1982 (The poetics of Cinema), pp. 32-54.

18 Nota-se que a escola marxista soviética não inventou, evidentemente, o que foi e é o princípio mais estável da compreensão não-acadêmica do funcionamento da literatura.

19 Medvedev, O Método Formal, p. 146; p. 107.

20 NT.

21 É em 'Kak sdelan "Don Kikhot”, aliás, que Shklovskii afirma o que mais tarde provocaria contestação direta de Bakhtin: 'a palavra é uma coisa' (slovo - veshch'); ver nota 35 abaixo.

22 V. N. Voloshinov, 'Slovo v zhizni i slovo v poezii' [1926], in Filosofiia i sotsiologiia gumanitarnykh nauk, pp. 59-86 (p. 59); 'Discourse in Life and Discourse in Poetry', Russian Poetics in Translation, 10, 1983 (Bakhtin School Papers), pp. 5-30 (p. 5) (em seguida, Voloshinov, 'Discourse in Life and Discourse in Poetry'). 
Tseitlin inicia reconhecendo o que foi anteriormente admitido por Plekhanov, e que irá, mais tarde, se repetir por Shklovskii em sua carta à Brik, ou seja, que 'uma estética marxista [...] continua não existindo/a não existir ${ }^{23}$. Em seguida, ele tenta unir as metodologias do formalismo e do 'sociologismo', mas em uma relação hierárquica bastante particular: uma 'análise puramente formal' da obra literária, que inicialmente envolverá a descrição e classificação dos 'fatos', não é apenas 'primária e essencial', mas é, de fato, o 'fundamento, sem o qual qualquer síntese sociológica [subsequente] é inconcebível'. ${ }^{24}$ Trotski desenvolve uma proposição muito similar, mas com uma valorização marcadamente diferente de cada 'fase' metodológica sucessiva: a obra de arte pode, como já vimos, ser julgada inicialmente 'de acordo com suas próprias regras/leis', mas este aspecto de metodologia literária deve aceitar seu papel essencialmente subsidiário (sluzhebnaia), seu status preparatório em relação ao cerne do negócio ‘científico’ no estabelecimento da significação social e ideológica da obra. Para Trotskii, a análise formal da obra literária desempenha a mesma função que a estatística nas ciências sociais e o microscópio para a biologia. ${ }^{25}$

Há duas dificuldades óbvias com esta junção muito conveniente de duas metodologias críticas divergentes: conforme as valorizações distintas de cada fase do processo oferecidas por Tseilin e Trotskii sugerem fortemente, e de acordo com o que Robert Maguire salientou, a prática crítica sempre tenderá a enfatizar um lado ou outro: a análise sociológica que busca se relacionar mais convincentemente ao texto através de meios essencialmente formal (suplementar), ou a análise formal que busca se 'justificar' trabalhando fora do texto com o contexto social. Mais fundamentalmente, entretanto, ambas versões desse método superficialmente integrado ou 'cambaleante' acabam por reafirmar precisamente o que elas se propuseram a resolver ou solucionar: a divisão fatal entre forma e conteúdo.

O fator que determina esta similaridade contra-intuitiva, e o qual é a base de nossa caracterização do marxismo e do formalismo como dois lados da mesma - estética material - moeda é o conceito compartilhado que ambas têm da materialidade da literatura. Se os eventos históricos, ou da vida doméstica, ou das relações de classe, etc. são meramente uma 'motivação do instrumento' vide formalismo inicial, ou constituem o conteúdo ideológico que deve ser absorvido, transformado e representado no 'receptáculo' literário, nenhuma das tendências duvida que é, de fato, o que é externo à obra literária, nos termos mais crus da ontologia, que constitui sua materialidade. As palavras de Medvedev levam, inexoravelmente, à 'desvalorização do conteúdo' ('nizvedenie soderzhaniia'), ${ }^{26}$ condenando as evidências do Formalismo e seu medo do significado, que, com seu 'não aqui' e 'não agora', consegue destruir o sofisma do trabalho e da completude de sua presença no aqui e no agora. ${ }^{27}$ Medvedev continua a descartar esta - Shklovskiana ou formalista-inicial concepção de materialidade nos seguintes termos conclusivos:

É inadmissível tratar a fabula (no sentido de um evento específico 'na vida'), o heroi, a ideia, e tudo ideologicamente significante em geral como materialidade, já que tudo isso não existe como real fora da obra. ${ }^{28}$

23 Ibid., p. 115.

24 Ibid., pp. 121-22.

25 Trotskii, Literatura e Revolução, p. 131; p. 193.

26 Medvedev, The Formal Method, pp. 148, 151; pp. 108, 110.

27 Ibid., p. 145; p. 105.

28 Ibid., p. 153; p. 112; grifo meu. 
O que é digno de nota, entretanto é que isto pode funcionar também como um descarte convincente de uma concepção marxista da materialidade do trabalho literário, se omitíssemos somente a palavra 'fabula' e substituíssemos pela interpretação que Medvedev traz nos parênteses. A desvalorização do formalismo do conteúdo pode ser colocada ostensivamente em oposição diametral ao Marxismo, mas ambos extremos são baseados em uma concepção amplamente compartilhada sobre o que consiste a materialidade do trabalho/obra literário/a. Para os formalistas, esta materialidade pré-literária pode ter sido concebida predominantemente em termos de fenômenos empíricos neutros, matéria prima para uma narratologia emergente/nascente/incipiente; para os marxistas, naturalmente, isto era profundamente ideológico, relacionado mais intimamente com o contexto social de qualquer fenômeno empírico e às suas imbricações com as 'relações de produção', a base para uma sociologia da literatura nascente/incipiente/emergente/latente. Para o "medo do sentido" do formalismo, leia-se o "medo da forma" marxista. A expulsão do conteúdo pelos formalistas e a negligência do marxismo pela forma são produzidas pela mesma ideia errada da materialidade da obra literária.

Entretanto, em 1924, quando Bakhtin citou pela primeira vez o espectro da "estética material" em "Problemas de conteúdo, material e forma", que foi destinado a manter-se sem publicação até 1974-75, sua rejeição a este conceito de materialidade é apenas - e talvez cruelmente - implícita. Bakhtin prevê (e, em vista da história da publicação, ecoa) a objeção de Medvedev ao conceito de 'vida' e 'realidade' sendo em qualquer sentido a matéria prima da obra literária, argumentando que a realidade "já é minuciosamente estetizada" ('uzhe sushchestvenno estetizovana') antes de entrar em contato com a arte:

Nós devemos lembrar de uma vez por todas que não há realidade em si, nenhuma realidade neutra que pode ser posta em oposição à arte: no ato de falar sobre realidade e pô-la em oposição a algo, nós também a definimos e avaliamos de alguma maneira particular (Bakhtin, 'O problema do conteúdo, do material e da forma na criação literária', p. 278; p. 276).

Bakhtin também acusa a 'poética contemporânea' da 'negação ao conteúdo' ('otritsanie sodershaniia'), ao descrevê-la tanto como aspecto da forma, ou como aspecto da materialidade. ${ }^{29}$ Bakhtin e Medvedev até empregam uma analogia aparentemente idêntica ao repudiar a ideia da matéria/materialidade como um elemento inerte da realidade pré-criativa, como o escultor trabalhando no mármore.

Aqui, entretanto, somos forçados a confrontar a problematização em dois níveis: Primeiro, precisamos pelo menos reconhecer a questão da autoria do Método Formal, que se mantém mais intratável do que o recurso de Medvedev e Bakhtin que uma analogia similar pode sugerir. ${ }^{30}$ Segundo, e mais importante, suas perspectivas se utilizam de analogia para abrir novas perspectivas sobre a questão da materialidade em si. O uso de Medvedev da analogia não pretende apenas caracterizar sua rejeição à associação da matéria com a fábula;

29 Ibid., p. 284; p. 282.

30 Assim como os fatores acadêmicos, ideológicos e até nacionais, algumas posições na questão de autoria têm sido parcialmente condicionadas pela história da publicação destes textos, em russo e em inglês. Deve ser, no mínimo, notado, entretanto, que a pouca evidência documental que há tende a apoiar a autoria 'física' de Medvedev; ver [M. M. Bakhtin], Besedy V. D. Duvakina s M. M. Bakhtinym, Moscow, 1996, pp. 77-78; 'Pis'ma' M. M. Bakhtina', Literaturnaia ucheba, 4-5, 1992, pp. 144-52. Ver também Iu. P. Medvedev, 'Pis'mo v redaktsiiu zhurnala “Dialog. Karnaval. Khronotop”, Dialog. Karnaval. Khronotop, 4, 1995, pp. 148-56; Iu. P. Medvedev, “"Nas bylo mnogo na chelne ...”, Dialog. Karnaval.Khronotop, 1, 1992, pp. 89-108. 
também é uma introdução à análise de uma segunda concepção bem diferente da 'matéria', a qual (ele) atribui à Viktor Zhirmunskii e mais tarde, de forma modificada, a Tynianov:

A própria palavra 'matéria', como está sendo utilizada aqui, é ambígua no mais alto nível. [...] Nos parece inadmissível falar sobre matéria/materialidade na arte somente como algo já encontrado pelo artista, e não como algo criado por ele de acordo com um plano artístico. [...] É possível tratar a linguagem como a matéria da literatura, como Zhirmunskii faz, pois a linguagem em sua especificidade linguística é de fato encontrada pelo artista individual/pelo indivíduo artista. ${ }^{31}$

Medvedev, buscando algo que poderia ser declarado como 'existindo como dado fora do trabalho/obra' e que não está 'minuciosamente estetizado', desempenha um ato de sutil artimanha retórica: ao negar a validade do que nós devemos agora chamar de primeira concepção formalista de material, para a qual nós utilizamos a iconoclastia militante de Shklovskii como um atalho conveniente, identifica agora uma segunda concepção de material, a qual o mesmo caracteriza como hiperformalista e hiper-abstrata, mas não ontologicamente e esteticamente inadmissível.

Medvedev, como devemos notar, questiona as limitações desta segunda concepção formalista de material/matéria/materialidade como linguagem, e não sua viabilidade fundamental.

Se Bakhtin fosse, de fato, o autor de O Método Formal, entretanto, seríamos obrigados a denominar isto como um ato de regressão retórica. No 'Problema de Conteúdo, Material e Forma na Criação Literária', ao prestar pouca atenção no primeiro conceito de material em associação com a fabula, o que está implicitamente ligado aos graus do oponente "indigno", Bakhtin utiliza a analogia de um escultor trabalhando o mármore afim de demonstrar a inadequação de seu segundo conceito de material como "linguagem em sua especificidade linguística"; ele antecipa, isto é, a inadequação a qual Medvedev volta sua atenção crítica para apenas rejeitar uma noção amplamente Shklovskiana da relação de material e fabula.

Para Bakhtin, em uma polêmica de caráter bastante diferente, a atividade do artista 'axiológica-artística' é direcionada não ao que é encontrado, mas sim à 'forma esteticamente significante/significativa do ser humano e seu corpo" ao 'objeto estético', o qual não pode simplesmente ser identificado com o material do qual é 'feito' ${ }^{32}$ A percepção da forma do artista é certamente impossível sem o mármore, tal como o é, incidentalmente, sem o cinzel, "que não é, em nenhum sentido, parte do objeto artístico". ${ }^{33}$ Onde a matéria é verbal, Bakhtin argumenta, 'a situação se torna, de alguma forma, mais complexa e não é mais tão obviamente absurda numa primeira observação [...] mas não é, em princípio, diferente. ${ }^{34, O}$ material assim concebido - em termos da segunda concepção formalista de material - toma uma forma/caráter quase instrumental, e qualquer 'estética material' se torna uma teoria de instrumentalidade, uma teoria de aspectos 'secundários, derivativos' ('vtorichnyi, proizdvonyi') da relação do artista com seu objeto.

31 Medvedev, O Método Formal, p. 153; p. 112. Medvedev cita antes o discurso explícito de Zhirmunskii do seu princípio em 'Zadachi poetiki' [1919] em V. M. Zhirmunskii, Theoriia literatury. Poetika. Stilistika. Leningrado, 1977, pp. 15-55: Medvedev, O Método Formal, p. 119; p. 85. A proposição de que a linguagem é o material da literatura é adotada/suposta, mas não discutida, no artigo que é o objeto mais direto da polêmica de Bakhtin em "O problema do conteúdo, do material e da forma na criação literária", ou seja, V. M. Zhirmunskii, 'K voprosu o "formal'nom metode"”' [1923], em Teoriia literatury. Poetika. Stilistika. Pp. 95-105

32 Bakhtin, 'O Problema do Conteúdo, Material e Forma na Criação Literária', p. 267; p. 265.

33 Ibid., p. 267; p. 265.

34 Ibid., p. 267; p. 265. 
O que é crucial aqui é que Bakhtin, em momento algum, associa a matéria, dentro do enquadramento da poética formalista, com fabula, com dados éticos e experienciais que precedem a obra literária. Ele não faz nenhuma tentativa de responder a inversão de Shklovskii da essência da vida e da mecânica da representação, e assume desde o início que a definição formalista operativa do material da arte verbal é simplesmente 'a palavra na linguística' ('slovo lingvistiki'), e que isto é precisamente o julgamento equivocado da natureza da 'palavra' que requer urgentemente reparação/compensação. Medvedev, ao escrever após Bakhtin, embarca em uma crítica de implicações da concepção da linguagem como um material inerte, e a obra artística como um "material organizado, como uma coisa", ${ }^{35}$ apenas após lidar com o "cerne genético' do formalismo, sua primeira concepção de matéria.

Assim, nós conseguimos identificar uma certa distância entre as 'declarações concretas', exteriorizadas, de Medvedev e de Bakhtin sobre esse assunto, apesar de suas origens em uma concepção declaradamente comum. ${ }^{36}$ Bakhtin não está primariamente preocupado com o conceito formalista inicial de matéria, e, na verdade, nunca se refere diretamente a ele. O corolário de tal conceito, ou seja, a usurpação de um conceito ideologicamente significativo por um 'dispositivo' técnico é implicitamente rejeitado na discussão da natureza 'já estetizada' da realidade e na 'negação do conteúdo’ pelo formalismo, as quais já discutimos, mas o conceito em si é aparentemente indigno de resposta explícita. ${ }^{37}$

Bakhtin, então, se concentra no segundo conceito formalista de matéria, na última proposição que consiste no fato de que é a linguagem em si que deve ser considerada o material da literatura, e coloca, de modo crucial, as conclusões fundamentalmente conflitantes que podem surgir desta premissa.

Isto marca, de alguma forma, não o fim, mas o início do engajamento de Bakhtin com o formalismo; é possível imaginar Bakhtin e, digamos, Zhirmunskii concordando provisoriamente com o fato de que a língua deve ser, de alguma forma, o material da obra literária, mas quaisquer definições resultantes da função da matéria e dos processos envolvidos em sua transformação na atividade estética permanecem separadas por seus conceitos fundamentalmente opostos de linguagem por si só.

35 Ibid., p. 266; p. 264.

36 É digno de nota, entretanto, que a questão de autoria é ainda mais complicada pela orientação do 'Uchenyi sal'erizm: o formal'nom (morfologicheskom) metode', escrito no fim de 1924 e publicado com o nome de Medvedev em 1925. Aqui, assim como 'O Problema com Conteúdo, Material e Forma na Teoria Literária', o foco é enfaticamente no segundo conceito formalista de matéria, e nós deixamos de atribuir a ênfase tardia de Medvedev sobre o conceito formalista inicial de matéria, no Método Formal à consistência maior do livro com o temperamento político, em oposição ao temperamento teórico, do período/da épica. Ver P. N. Medvedev, 'Uchenyi sal'erizm: o formal'nom (morfologicheskom) metode', Bakhtin pod maskoi. 5/1: Maska piataia, pervaia polumaska, Moscow, 1996, pp. 10-24; ver também Nikolai Nikolaev, 'Publishing Bakhtin: A Philological Problem (Two Reviews)', Dialogism, 4, 2000, pp. 67-111, que faz um caso empático e detalhado da autoria comum de 'O Problema com Conteúdo, Material e Forma na Teoria Literária' e 'Uchenyi sal'erizm', mas que falha na sustentação da implicação que se estende ao Método Formal. 'O literaturnom fakte', obra de Tynianov, publicada entre a escrita de O Problema do Conteúdo, Material e Forma na Teoria Literária’ e 'Uchenyi sal'erizm', é citado no último. Existem, como veremos, bases para supor que é de desenvolvimento particular de Tynianov do formalismo na segunda parte dos anos 1920 que provoca a diferenciação maior de Medvedev entre as duas concepções formalistas de matéria no Método Formal; ou, em outras palavras, que é Tynianov que 'revela' a instabilidade da abordagem formalista em relação à matéria. Veja Iu. N. Tynianov, 'O literaturnom fakte', Lef, 2, 1924, pp. 101-16; citado em Iu. N. Tynianov, 'Literaturnyi fakt', in Arkhaisty i novatory, Leningrad, 1929, pp. 5-29 (hereafter, Tynianov, 'Literaturnyi fakt').

37 Bakhtin, O Problema com Conteúdo, Material e Forma na Teoria Literária, pp. 278, 284; pp. $276,282$. Isto também é uma importante premissa teórica da breve análise de Bakhtin da obra de Pushkin "Remembrance" (Vospominanie): Bakhtin, 'O Problema com Conteúdo, Material e Forma na Teoria Literária', pp. 297-300; pp. 296-98. 
Bakhtin, mais tarde, põe a linguística à prova pelo seu conceito empobrecido do que ele insiste em chamar de língua viva ${ }^{38}$ mas neste estágio inicial em seu próprio engajamento com a linguagem é o imperialismo da linguística, em oposição à sua inadequação (de algum modo implícita), que é sua preocupação primária: a análise linguística deve se restringir à "maestria" (ovladenie) de seu próprio objeto (a respeito do qual a linguística não progrediu para além da sentença complexa), ao invés de especular em torno do 'significado [das particularidades puramente linguísticas da própria linguagem] para a arte, para a ciência e para a religião, uma tarefa mais apropriada para a estética e para a ciência cognitiva. ${ }^{39}$

Bakhtin acusa, essencialmente, a linguística de tentar se passar por estética, de restringir a análise da natureza estética e da função da arte verbal em suas metodologias implicitamente inapropriadas. Mais especificamente, ele acusa a 'poética contemporânea', cada vez mais convencido do significado da base material linguística para literatura, de aderir à linguística abstrata em um projeto que culminará no 'empobrecimento' (obednenie) do objeto da poética, e até na substituição [podmena] de seu objeto [...] por algo bem diferente' ${ }^{40}$

O perigo imediatamente percebido é, portanto, a inscrição de uma análise da linguística abstrata na construção de uma nova poética 'imanente'. Apesar da 'produtividade e significância indubitável' de certas obras produzidas pelos 'representantes do então chamado método formal ou morfológico', ${ }^{41}$ o problema é que

a poética é ligada fortemente à linguística, temendo ir um passo mais adiante do que ela (no caso da maioria dos formalistas e de V. M. Zhirmunskii), e às vezes fazendo esforços diretos para tornar-se apenas uma divisão da mesma (no caso de $V$. V. Vinogradov).

Para a poética, como para qualquer estética especializada, na qual é necessário considerar a natureza da matéria (neste caso especifico - verbal) bem como nos princípios da estética geral, a linguística é, sem dúvida, necessária como uma disciplina subsidiária; porém aqui ela começa a ocupar uma posição de liderança inapropriada, quase que justamente a posição que deveria ser ocupada pela estética geral (Ibid., p. 263; p. 261.).

As implicações para a nossa compreensão da história do formalismo na Rússia, e seu impacto posterior no ocidente, são bastante surpreendentes: poderia parecer que os formalistas, apesar de uma certa tendência voltada para a inovação terminológica, não tinham fixado uma concepção de matéria na produção literária. Isto foi observado, mas não resolvido de alguma forma, por Viktor Erlich em "Russian Formalism: History - Doctrine", que questiona se a 'matéria' constitui-se do 'objeto-problema da realidade incorporado na literatura, ou seu meio, a linguagem'. A resposta reveladora de Erlich é que, apesar de 'não haver aparentemente uma unanimidade entre os porta-vozes formalistas e quasi-formalistas' a esse respeito, a 'última interpretação parece ter prevalecido' (esta tentativa extrema de não-conclusão é precedida, incidentalmente, por instâncias conflitantes traçadas

38 'A palavra não é uma coisa' ('Slovo ne veshch'), Bakhtin escreve, mais tarde, em seu livro sobre Dostoiévskii: Problemy tvorchestva/poetiki Dostoevskogo, Kiev, 1994, p. 418; Problemas da Poética de Dostoiévski ed. and trans. Caryl Emerson, Minneapolis and London, 1984, p. 202.

39 Bakhtin, 'O Problema do Conteúdo, da Matéria e da Forma' (The Problem of Content, Material and Form), p. 293; p. 292.

40 Ibid., p. 260; p. 258.

41 Ibid., p. 261; p. 258. 


\section{Conexão Letras}

por Shklovskii, que 'pagou sua dívida às duas interpretações antagônicas; consistência ou clareza terminológica não era seu forte').$^{42}$ A implicação é de que isto constituirá um defeito congênito no 'sistema' formalista, conforme foi sugerido por Bakhtin - uma estética material baseada em uma compreensão equivocada da 'matéria' em si - ou, de forma alternativa, uma defesa contra a mesma implicação, será o objeto de outros comentários posteriores.

As implicações - embora secundárias - da nossa compreensão das relações de Bakhtin com um de seus co-pensadores, entretanto, são mais claras, de alguma maneira: há algo de paradoxal no fato de que no trabalho inicial de Bakhtin, ele não dá atenção explícita para a primeira fase do desenvolvimento formalista, ignorando virtualmente, como já vimos, a primeira definição formalista de matéria.

O trabalho posterior de Medvedev, apesar de ter o escopo coberto no período de meados de 1920, quando esta concepção de matéria (juntamente com grande parte do pensamento formalista) passa por uma revisão fundamental, discutindo o 'núcleo genético' do formalismo, os princípios fundadores da sua análise não permitirão superá-lo, e movem-se apenas tardiamente para o solo que Bakhtin ocupa desde o início.

A contribuição de outro co-pensador de Bakhtin é relevante tanto em relação ao aspecto teórico como em relação aos aspectos bio-bibliográficos do problema. $\mathrm{O}$ artigo de Voloshinov publicado em 1926 denominado 'Discourse in Life and Discourse in Poetry' (O Discurso na Vida e o Discurso na Poesia) também foi atribuído à Bakhtin, mas, do mesmo modo que $O$ Método Formal, também cede credibilidade à hipótese da autoria distinta quando lido como uma contribuição ao problema da matéria. Distinguindo duas visões 'falsas' da produção literária, a primeira concentrando-se na psicologia do autor ou do leitor, e a segunda expulsando o autor e o leitor em favor da 'fetichização da obra artística como coisa', ${ }^{43}$ Voloshinov, utilizando um qualificador que foi cada vez mais favorecido pelos próprios formalistas, nomeia o 'então chamado método Formal' como uma espécie da última hipótese: ${ }^{44}$

Para [o Método Formal] a obra poética é matéria verbal, organizada pela forma de maneira particular. Além disso, [o Método Formal] considera o discurso não como uma entidade sociológica, mas de um ponto de vista linguístico abstrato [...]. Compreendido mais amplamente, no entanto, como produto da interação cultural, o discurso deixa de ser um objeto auto-suficiente e não pode mais ser compreendido independentemente da situação social em que é produzido. [...] Na verdade, se nos mantivermos dentro dos limites do aspecto objetivado da arte, é impossivel indicar as fronteiras da matéria e seus aspectos que tenham significação artística.

A matéria em si combina diretamente com o ambiente circundante extra-artístico e possui uma quantidade infinita de facetas e definições - matemáticas, fisicas, químicas, e finalmente, linguisticas (Voloshinov, 'Discourse in Life and Discourse in Poetry', p. 63; p. 8.).

42 Viktor Erlich, Russian Formalism: History — Doctrine, The Hague, 1980 [1955], p. 189.

43 O segundo, na verdade, duplamente falso no ponto de vista de Voloshinov, uma vez que isso apenas finge ter uma objetividade científica, mas, em última análise, e visando inevitavelmente a natureza fundamental do objeto das ciências humanas, faz seu próprio contrabando 'subjetivista': Voloshinov, Marxismo e Filosofia da Linguagem, p. 277; p. 62.

44 Nos meados dos anos 1920, na Rússia, tornou-se quase compulsório o uso dos termos "Método Formal" e "Formalismo" firmemente em aspas, ou apenas apresentá0los com o epíteto 'chamado' ('tak nazyvaemyi'). Esta prática não era, de forma alguma, restrita aos oponentes do Formalismo: ver, por exemplo, Osip Brik, 'Tak nazyvaemyi formal'nyi metod', Lef, I, 1923, pp. 213-15; 'The So-Called Formal Method', Russian Poetics in Translation, 4, 1977 (Formalist Theory), pp. 90-91. 
Aqui, como em outras passagens do 'Discurso na Vida e Discurso na Poesia', Voloshinov repete as preocupações de Bakhtin e Medvedev em relação à ilusão da poética contemporânea de imanência, e a fetichização/reificação da produção literária, sua atração fatal para a linguística abstrata, e sua falta de habilidade em distinguir a arte verbal daquilo que é meramente verbal. Ele, contudo, também explicita claramente o que havia sido abordado apenas implicitamente no tratamento anterior de Bakhtin em 'O Problema de Conteúdo, Material e Forma' - ao dizer que o problema não recai na concepção de matéria como linguagem, mas preferivelmente na concepção de linguagem tratada como sendo abstrata.

Apesar de Voloshinov prefaciar sua definição de matéria ao opor os caminhos igualmente 'falsos' da abordagem imanente à produção literária (Formalismo) e o subjetivismo psicológico que tem caracterizado a crítica literária tradicional, estes elementos não são opostos de modo dialético, e Voloshinov não procura a síntese destes.

O desenvolvimento proposto por Voloshinov é, de fato, muito mais sutil e inesperado. Ele faz referência, como já vimos anteriormente, à tentativa de Sakulin de desenvolver um 'método sociológico' mais sofisticado ao distinguir as séries 'imanentes' e 'causais' nas quais a obra literária tem sua existência, e nos termos pelos quais elas devem ser estudadas. Voloshinov, no entanto, escrevendo ostensivamente a partir de um ponto de vista marxista mais amplo, não está preocupado em adjudicar entre as reivindicações das abordagens 'imanentes' e 'sociológicas' concebidas nestes termos, e rejeita a ideia de que a análise sociológica (histórica, social, diacrônica) irá seguir corretamente e 'completar' a análise imanente (poética, sincrônica).

Voloshinov nos leva para além do problema inicial que identificamos com a metodologia 'cambaleante' de Sakulin, isto é, de que a prática crítica sempre tenderá a enfatizar uma fase deste processo em detrimento de outra, e oferecer, ao invés disso, uma alternativa metodológica bastante distinta, que atenta para o que se volta e está de fato baseada no problema da matéria. Voloshinov não traz o 'método sociológico' como uma alternativa direta à especificação imanente e anti-social da poética contemporânea (formalismo), mas busca, ao invés disso, transformar o método sociológico em uma poética sociológica, que irá rejeitar a distinção metodológica entre 'imanente' e 'causal' assim como rejeita a separação entre o material verbal e não-verbal. O método sociológico é reprovado por falhar em 'fazer uma única tentativa séria de estudar com seus próprios métodos a então chamada estrutura imanente do trabalho artístico’ (Ibid., p. 60; p. 6). Mas como poderia?

O método precisa deixar que os outros, poetas políticos, completem essa tarefa antes que ela se torne sua obrigação. De moto alternativo, em uma maneira que prefigura a direção tardia da crítica literária soviética, a análise sociológica poderia preceder a análise poética, deixando para a última, apenas irrelevâncias relativas.

Para Voloshinov, entretanto, o 'sociológico' e o 'imanente' são termos meros de uma falsa oposição, e essa questão que deveria preceder outra é, então, evitada. Estas questões são fundadas em uma falsa oposição a partir da qual iniciamos, e a qual produz concepções alternativas, mas igualmente problemáticas de matéria: a análise sociológica toma a primeira concepção formalista de matéria como seu ponto de partida, que leva à questão de sua expressão na forma linguística; a análise imanente começa a partir da segunda concepção imanente de matéria, e somente a partir daí considera (se considerar de fato) a relação entre a matéria da produção literária e a matéria da 'vida'. A concepção de matéria que unifica os fenômenos extra-linguísticos (o domínio inicial da análise sociológica) anula metodologicamente a distinção entre as abordagens imanentes e sociológicas. Voloshinov, por fim, define a arte como 'sociologicamente imanente' ('immanentno-sotsiologichno') 


\section{Conexão Letras}

e o que é uma descrição alternativa da dinâmica de uma nova concepção de matéria, "O ambiente social extra-artístico, que influencia [a arte] por fora, encontra nela uma resposta interna direta. Não é o caso de uma entidade extraterrestre influenciando outra, mas sim de uma construção social influenciando outra." (Ibid., p. 62; p. 7)

Todas as abordagens 'falsas' ou parciais as quais Voloshinov se refere - a abordagem imanente, a abordagem sociológica, e até a desacreditada abordagem psicológica subjetivista da era 'pré-científica' - compartilham uma tendência em comum: de confundir a parte com o todo.

Na análise de Voloshinov, as más apreensões destas abordagens parciais do estudo da literatura são espelhadas perfeitamente por suas respectivas considerações fatalmente parciais do material literário. Embora Medvedev e Bakhtin tenham sido igualmente contundentes em seus diagnósticos, nenhum (pelo menos neste aspecto, no caso de Bakhtin) ofereceu os meios para superar estas deficiências metodológicas;

Voloshinov, entretanto, exige em última instância uma confluência das abordagens críticas alternativas e aparentemente contrárias (sociológica e imanente), uma confluência que é predicada em relação a uma concepção de matéria literária completamente nova. Para Voloshinov, o material da produção literária é, de fato, a linguagem, mas a linguagem entendida como "Forma particular de interação social, que é percebida e fixada na matéria do trabalho artístico." 45

Deste modo, Voloshinov se volta para a possibilidade de uma nova 'poética', para uma vertente literária de uma nova 'estética material', que será fundada a partir da inseparabilidade dos fenômenos da vida real e do discurso ou, em outras palavras, a indivisibilidade da matéria.

Esta é a ligação crítica entre a obra de Bakhtin 'O problema do Conteúdo, da Matéria e da Forma' e a discussão posterior de Medvedev de uma 'translinguística' embrionária em 'O Método Formal', que desenvolve a proposição indefinida de Bakhtin do 'enunciado' tomado como a unidade básica de uma linguística concreta (em oposição à linguística abstrata) sob a influência da redefinição programática de Voloshinov de matéria.

Medvedev identifica a ligação perdida 'que une a presença material da palavra com seu significado' como uma 'avaliação social' ('sotsial'naia otsenka'). ${ }^{46}$ Sendo assim, a avaliação social pode não ter nenhuma relação com o exemplo linguístico, que é somente um 'enunciado condicional' ('uslovnoe vyskazyanie'), em oposição à 'performance discursiva concreta' (konkretnoe rechevoe vystuplenie') que corresponde ao enunciado social ${ }^{47} \mathrm{e}$, deste modo, a poesia em si (e, por extensão, toda a produção literária) deve ser compreendida não como um domínio hermeticamente fechado para uma análise linguística de forma abstrata, mas como um tipo de enunciado concreto, cognato com uma variedade infinita de outros tipos de enunciados associados com os várias condições não-literárias da performance linguística. ${ }^{48} \mathrm{Ou}$, para retornar aos termos específicos da presente análise, ao rejeitar a concepção formalista inicial de matéria como motivação do instrumento, Medvedev parafraseia uma rejeição unificada de Bakhtin da segunda concepção de matéria como linguagem argumentando que:

45 Ibid., p. 64; p. 9.

46 Medvedev, The Formal Method, p. 162; p. 119.

47 Ibid., p. 166; p. 122.

48 Ibid. pp. 171-74; pp. 126-28. Falando francamente, a referência cruzada aqui deveria ser à Voloshinov, o proponente mais expansivo e explícito da base social da linguagem dentro da escola de Bakhtin: Ver parte dois de Marxismo e Filosofia da Linguagem. 
A linguagem, entendida como totalidade ou sistema de possibilidades linguísticas (fonética, gramatical, lexical), é, menos que todas, a matéria da poesia. O poeta não escolhe as formas linguísticas, mas as avaliações que são depositadas nelas (Medvedev, The Formal Method, p. 166; p. 122).

Na obra de Bakhtin "O problema do conteúdo, do material e da forma na criação literária", dentro do qual este princípio encontra sua primeira confirmação, é famosamente prefaciada por sua asserção sobre a liberdade do artigo "do lastro supérfluo de citação e da referência, [...] desnecessária para o leitor competente, e que não auxilia de forma alguma o leitor incompetente' ${ }^{49}$ Isto, como já vimos anteriormente, é lançado de forma ainda mais dramática por Medvedev em sua ênfase posterior a respeito da concepção formalista inicial sobre a matéria no Método Formal. A questão do engajamento real de Bakhtin com a fase inicial do formalismo é, então, enterrada sob uma camada de dúvidas e depende da boa-vontade do leitor em 'confiar' em Bakhtin, que faz repetidas referências (talvez sem muito suporte) ao seu suposto 'melhor oponente', Zhirmunskii. ${ }^{50}$

\section{IV}

O fato de que Medvedev deveria focar em sua análise de uma segunda concepção formalista de matéria não focada em Zhirmunskii, mas em Tynianov, autor esse ao qual Bakhtin não faz nenhuma referência direta é, de fato, completamente consistente com o período da escrita da obra. ${ }^{51} \mathrm{O}$ reconhecimento de Medvedev de pelo menos a possibilidade

49 Bakhtin, 'The Problem of Content, Material and Form', p. 259; p. 257. Bakhtin pode não estar, de fato, se referindo ao debate crítico imediato a partir do qual nenhuma parte interessada poderia estar imune, mas ao chamado formalismo europeu de Wölfflin, Hildebrand, Fiedler e Worringer, o qual Medvedev posteriormente dedica um capítulo do Método Formal, 'The Formal Method in European Art Scholarship'. Devemos, entretanto, tomar cuidado ao atribuir muito significado a estas fontes, como de fato afirma Medvedev: 'É fato que não é possível exibir que nossos formalistas dependeram diretamente de seus predecessores do leste europeu. Ao que tudo indica, não havia conexão genética direta entre eles. Nossos formalistas geralmente não contam com ninguém e não citam ninguém que não sejam eles mesmos': Medvedev, The Formal Method, p. 59; p. 41. Compare o desprezo mal humorado de Rosaliia Shor a respeito da ignorância formalista a qual ela caracteriza como uma antiga tradição da análise formal no ocidente, particularmente da escola alemã: R. O. Shor 'Formal'nyi metod na zapade' in Ars Poetica, I, ed. M. A. Petrovskii, Moscow, 1927, pp. 127-43.De outra forma, Bakhtin pode estar escolhendo deliberadamente 'engajar-se com o outro' de uma maneira que a escola ocidental considerou ousada: ver por exemplo Ladislav Matejka, 'Deconstructing Bakhtin in C.A. Mihailescu e W. Hamarneh (eds), Fiction Updated: Theories of Fictionality, Narratology and Poetics, Toronto, 1996, pp. 257-66, que situa as origens das ideias de Bakhtin sobre a forma e matéria em uma dívida desconhecida em Broder Christiansen Philosophie der Kunst [1909]. Para um panorama das fontes filosóficas que possam ter condicionado a abordagem de Bakhtin para as questões de forma e matéria, ver Craig Brandist, The Bakhtin Circle: Philosophy, Culture, Politics, London and Sterling, VA, 2002, pp. 15-52.

50 Bakhtin também faz referências explícitas a Eikhenbaum como prefácio à sua discussão sobre as várias formas literárias no discurso duplo na primeira edição de seu livro sobre Dostoiévski, Problemy tvorchetsva Dostoevskogo, in Bakhtin, Problemy tvorchestva/poetiki Dostoevskogo,p. 90, p. 406. Para tradução em Inglês, ver Bakhtin, Problems of Dostoevsky's Poetics, p. 191. Ver também a resposta direta à questão que Skhklovskii levanta 'a palavra é uma coisa', a qual já comentamos, um momento no qual a 'polêmica' de Bakhtin com o formalismo é tudo menos 'escondida' (notas 19 e 37 acima).

A questão do engajamento de Bakhtin com seu 'outro' especificamente formalista forma o pano de fundo para a obra de Michael Holquist 'Bakhtin and the Formalists: History as Dialogue', in Robert Louis Jackson and Stephen Rudy (eds), Russian Formalism: A Retrospective Glance, New Haven, CT, 1985, pp. 82-95, onde Holquist propõe uma oposição entre Bakhtin como 'pensador russo do formalismo' (p. 82); ver também Igor' Shaitanov, 'Zhanrovoe slovo u Bakhtina i formalistov', Voprosy literatury, May-June, 1996, pp. 89-114; 'The Concept of the Generic Word: Bakhtin and the Russian Formalists', in Carol Adlam et al. (eds), Face to Face: Bakhtin in Russia and the West, Sheffield, 1997, pp. 233-53.

51 Bakhtin pode não ter tido conhecimento a respeito da obra de Tynianov 'Oda kak oratorskii zhanr', publicado em 1922, embora este confronto inovador sobre a relação entre a literatura e a 'não-literatura' iria se 
de mudança na concepção formalista de matéria é feito com o seu agora familiar ceticismo retórico. Sua descrição e rejeição de uma "Segunda concepção de 'Matéria' na obra de Tynianov" é prefaciada por uma atualização de sua convicção de que a primeira concepção formalista de matéria "é parte de um componente crucial e inalienável do sistema formalista' ${ }^{52}$ Igualmente, ao confirmar que Tynianov concebe a ideia de matéria 'como linguagem, e nunca como motivação do dispositivo (instrumento)', Medvedev caracteriza isso como uma 'adesão [...] ao conceito de matéria de Zhirmunskii', e uma adesão que é acompanhada por lapsos ocasionais em relação à primeira concepção, 'sem nenhuma consideração metodológica'. ${ }^{53}$

Duas obras publicadas em 1924 poderiam parecer confirmar o julgamento de Medvedev: The Problem of Verse Language abre uma afirmação aparentemente inequívoca a respeito da natureza especificamente verbal da matéria, e a conviç̧ão de que a questão central para os estudos literários em sua relação com tal matéria, a qual Tynianov chama de 'o princípio construtivo', e os meios pelos quais a matéria é transformada em processo literário $;^{54} \mathrm{em}$ 'Literaturnyi fakt', contudo, faz parecer Tynianov vacilar entre a primeira e a segunda concepção de matéria, às vezes confirmando a interação essencial da 'matéria verbal' ('rechevoi material') e os fatores construtivos que o organizam, às vezes "caindo", de fato, considerando os elementos pré-literários históricos ou experienciais de uma fabula potencial como material a partir do qual os fatores construtivos se 'aplicam'..$^{55}$

Esta aparente inconsistência na reformulação de Tynianov do conceito de matéria pode ser, entretanto, igualmente atribuída à natureza inovadora de seu pensamento e sua real incerteza no que diz respeito a todas suas implicações. ${ }^{56}$ No entanto, The Problem of Verse Language não é apenas um reconhecimento claro da influência crescente da associação entre matéria e linguagem no seu pensamento; a obra também atenta para o início de uma problematização da relação entre a matéria verbal e 'não-verbal' e para um questionamento acerca da real viabilidade de tal distinção. ${ }^{57}$

provar altamente significativo para a escola bakhtiniana: Tynianov, Poetika, pp. 227-52. Referência direta à Tynianov em Bakhtin é, ironicamente, limitada a uma avaliação completamente negativa à produção literária de Bakhtin, mediada pelas anotações 'secretas' de palestras feitas por R. M. Mirkina no período entre 1922 e 1927: 'Tynianov [...] não possui nem o estilo nem a linguagem que permitiria a ele criar um trabalho artístico. 'Kiukhlia' só pode ser visto como um livro de leituras para o ensino médio. Lev Tolstói [...] trabalhou por vários anos nos materiais de Guerra e Paz. Tynianov produziu seu trabalho em duas semanas': M. M. Bakhtin, 'Letskii po russkoi literature (1922-1927 gg.)', Dialog. Karnaval. Khronotop, I, 1993, 2, pp. 97-104. As palavras russas material ou materialy são usadas aqui no sentido convencional de 'fontes', sem nenhuma referência implícita ao problema teórico que estamos trabalhando.

52 Medvedev, O Método Formal, p. 159; p. 116.

53 Ibid., pp. 160, 159; p. 117. Em uma atitude que pode indicar um aprofundamento da espiral de influências operantes no processo de transmissão formalista. Na tradução de O Método Formal para o Inglês, o tradutor Albert J. Wehrle utiliza uma expressão um tanto indevida 'fortuita', exatamente o mesmo termo Erlich utiliza para caracterizar a ampla 'retirada' do formalismo (Erlich, Russian Formalism, p. 129).

54 Iu. N. Tynianov, Problema stikhotvornogo iazyka, The Hague, 1963 [1924]; The Problem of Verse Language, ed. and trans. Michael Sosa and Brent Harvey, Ann Arbor, MI, 1981.

55 Tynianov, 'Literaturnyi fakt', p. 16; p. 19.

56 Vladimir Novikov concede uma falta 'definitiva, embora historicamente perdoável' de 'desenvolvimento explícito do conceito de matéria em todos seus aspectos e nuances' no trabalho de Tynianov e seus colegas: Iu. N. Tynianov, Literaturnaia evoliutsiia: izbrannye trudy, ed. Vladimir Novikov, Moscow, 2002, p. 476. De outro modo, Medvedev, talvez não surpreendentemente levando em conta a nossa discussão anterior, está preparado de outra maneira para chamar Tynianov de 'o líder formalista mais cauteloso, comedido e acadêmico’: P. N. Medvedev, Formalizm i formalisty, Leningrad, 1934, p. 171.

57 Marc Weinstein fez um estudo detalhado das (quatro) diferentes denotações do termo 'matéria' em Tynianov, mas com o propósito infeliz de distanciá-lo de Bakhtin, cuja estética é caracterizada apenas como uma 
Tynianov estabelece a matéria verbal como o primeiro lócus para o estudo de arte verbal ao se referir não apenas à matéria, mas à 'matéria formada, o marcador convencional mais simples que é o discurso, a palavra'. ${ }^{58}$ A palavra 'formada' (oformliaemyi) poderia inicialmente parecer sugerir a insistência de Tynianov na concepção de uma separação fundamental entre matéria e sua expressão linguística (seu 'receptáculo'): isto é, ele persiste na ilusão positivista que na ocasião distraiu Shklovskii, e que permite que o artista apenas encontre e 'forme' o material, mas não o crie. A inferência mais crítica, no entanto, é que é impossível falar de quaisquer fenômenos culturais ou experienciais como apenas 'encontrados'. Isto é suportado pelo desenvolvimento de Tynianov em 'Literaturnyi fakt' da ideia de que a obra literária é essencialmente a aplicação (prilozhenie) do fator construtivo à linguística material, isto se transforma no processo de 'formação do material' ('v oformlenii materiala'). ${ }^{59}$ Os fenômenos culturais, históricos ou experienciais, a 'matéria' do conceito inicial formalista, devem sempre ser construídos (na verdade, até certa medida eles já são construídos) no meio da linguagem; em outras palavras, "não há realidade em si, nenhuma realidade neutra que pode ser posta em oposição à arte'porque a 'vida' e a 'realidade' já são 'minuciosamente estetizadas' ${ }^{60}$ Além disso, este processo de construção, sendo ou não especificamente relacionado à criação de uma obra especificamente 'literária', já implica em si na construção também da forma: ${ }^{61}$ 'matéria' não é, de maneira alguma, oposto a 'forma'; material também é 'formal', porque ela não existe aparte do [fator] construtivo. ${ }^{62}$

A base para essa resolução harmonizadora e abrangente do problema do material na obra literária oferece a maior pista sobre o motivo pelo qual o problema provocou tantas exposições variadas do trabalho de vários críticos formalistas na obra do próprio Tynianov (às vezes, aparentemente, dentro de uma mesma obra), e em diferentes respostas críticas a esses trabalhos feitos por Medvedev e Bakhtin. Tynianov não substitui, de fato, uma concepção de matéria por outra, como Medvedev sugere: Ele combina ambas concepções em uma formulação que tem a capacidade inesperada de resistir:

recapitulação contraditória de suas raízes essencialmente Kantianas. Weinstein, tendo em vista ironicamente a ênfase deste artigo (e de Tynianov) na evolução, se contenta em manter Bakhtin congelado no ano de 1924, o que é equivalente - se não for muito pior - a insistir na associação indissociável de Tynianov com o formalismo inicial; ver Marc Weinstein, 'Le débat Tynjanov / Bakhtin ou la question du matériau', Revue des Études Slaves, 64, 1992, 2, pp. 297-322. Aleksander Skaza, de forma oposta, traz uma leitura altamente sensível sobre o significado de matéria em Bakhtin, mas persiste em opor isso a uma 'posição' Formalista indiferenciada, o que não só engloba Tynianov e Shklovskii, mas também engloba - e apaga - o desenvolvimento cronológico de cada uma de suas posições respectivas; ver Aleksander Skaza, 'Kontseptsiia “material'noi estetiki” M. M. Bakhtina v polemike s formal'nym metodom: neskol'ko zametok', in Miha Javornik et al. (eds), Bakhtin and the Humanities: Proceedings of the International Conference in Ljubljana, October 19-21, 1995, Ljubljana, 1997, pp. 45-55.

58 Tynianov, The Problem of Verse Language, p. 7; p. 31.

59 Tynianov, 'Literaturnyi fakt', p. 15.

60 Bakhtin, 'The Problem of Content, Material and Form', p. 278; p. 276. Aqui, como em vários momentos deste artigo, o objeto e a terminologia de Bakhtin constroem claramente uma parte de seu público alvo como sendo familiar à luta neo-Kantiana com o idealismo e, juntamente com sua observação inicial a respeito do 'lastro supérfluo de citação e referência', ironicamente sinaliza a relativa ignorância do restante - entre esses, presumidamente, estão seus oponentes formalistas. As fontes filosóficas de Bakhtin, e em questões particulares de influência, não são, entretanto, a preocupação do presente artigo; ver sobre em, Brandist, The Bakhtin Circle: Philosophy, Culture, Politics.

61 A distinção crítica aqui não é entre literário e não-literário, mas entre externalizado (representado artisticamente, expresso pragmaticamente) e discurso 'interno', que determina, em última instância, toda a questão de forma e gênero em Bakhtin.

62 Tynianov, 'Literaturnyi fakt', p. 15. 
1. Ao escárnio de Medvedev à tendência formalista de tratar a fabula como matéria 'já que tudo isso não existe como um dado fora da obra',63

2. À crítica de Bakhtin e Medvedev a respeito da 'abstração' da linguagem que é implícita por sua concepção como matéria 'inerte'. Tynianov rejeita implicitamente a 'A linguagem, entendida como totalidade ou sistema de possibilidades linguísticas (fonética, gramatical, lexical)' como base para uma teorização da matéria literária, ${ }^{64} \mathrm{e}$ ao fazê-lo supera a crítica de Bakhtin em relação à visão da produção literária como sendo meramente um 'material organizado, como uma coisa' ${ }^{65}$

Não existe 'matéria' sem linguagem, mas igualmente, igualar matéria com linguagem é incluir em sua definição todos os diversos fenômenos culturais, históricos e experienciais previamente associados com fabula e com a motivação de seu instrumento. Tynianov combina os dois conceitos de material por conta da inseparabilidade fundamental dos fenômenos 'em vida' e as inúmeras formas de sua instanciação (construção) linguística. $\mathrm{Ou}$, pelo menos, Tynianov nos permite inferir tal junção, e que foi deixada para que o editor atual de suas obras, Vladimir Novikov, a tarefa de reapresentar este novo conceito de matéria nos seguintes termos:

Matéria é toda a realidade pré-criativa da produção artística: sua base verdadeira/empírica ou histórica; a diversidade de ideias abstratas refletidas nela; a totalidade de emoções extra-estéticas e as realidades naturais e objetivas recriadas pelo autor; e a linguagem em sua especificidade linguística. ${ }^{66}$

Isto não é apenas uma resolução útil das dificuldades na reformulação de Tynianov do conceito de matéria, mas isso define também o ponto no qual a comparação direta com Bakhtin se torna produtiva - a base para uma resposta à pergunta sobre como a realidade é estetizada nas diferentes fases da criação artística verbal. Inicialmente o que é surpreendente e ainda importante no resumo de Nonikov não são os termos particulares que ele opta por caracterizar os primeiros três componentes aparentemente 'não- ou extra-verbal' de 'toda a realidade pré-criativa da produção artística', mas o que é implícito a respeito da relação entre estas três categorias e a categoria final, 'linguagem em sua especificidade linguística. A língua é libertada da abstração e da 'inércia' do ato de ser forçada a co-habitar ou habitar, trazer à existência o que era previamente confundido pelo conteúdo 'não-linguístico': assim como a matéria não pode ser 'amorfa', a mesma também não pode ser vazia/esvaziada de conteúdo (o que, por sua vez, não pode ser concebido isolado da língua).

A reformulação de Tynianov no conceito do material literário repousa sobre a ideia dupla de que a língua e a 'realidade' (e a arte) não podem ser separadas, e que o material literário é formado no processo da performance verbal concreta. Ele chega perto de uma declaração definitiva da relação mutualmente constitutiva entre a linguagem e os 'fenômenos' ideológicos ou experienciais (devemos chamá-los adequadamente de 'possibilidades') em 1924, no livro 'Literaturnyi fakt'. Sua postura pode, portanto, ser denominada quase 'Bakhtiniana' em seu reconhecimento de que a língua em si só pode ser concebida em termos de performance concreta (a manifestação externa de tal, neste caso, é a escrita). ${ }^{67}$ Devemos notar que tudo isso, embora seja direcionado à resolução do problema do ma-

63 Medvedev, The Formal Method, p. 153; p. 112; e acima.

64 Ibid. p. 166; p. 122; e acima.

65 Bakhtin, 'The Problem of Content, Material and Form', p. 266; p. 264; e acima.

66 Tynianov/Nonikov, Literaturnaia evoliutsiia, p. 47; grifo meu - RA (Referência do Autor?).

67 Embora toda performance linguística seja processual, e não pode ser reduzida ou identificada completamente com sua manifestação externa, é o momento onde o processo adquire forma externa que deve dominar quaisquer análises dentro de uma abordagem especifica da crítica literária. 
terial literário, não implica necessariamente na 'dependência da realidade em instâncias especificamente literárias da personificação/incorporação estética; a atividade estética é, para Bakhtin, um componente de qualquer interação consciente com o mundo, e Tynianov também se aproximará desta posição/opinião no artigo de 1927 'On Literary Evolution' ${ }^{68}$ Isso parece apresentar, contudo, certas dificuldades lógicas, na medida em que a 'realidade' depende para sua 'existência' de uma construção estética, que inclui, mas não se restringe à construção literária ou artística; Tynianov parece correr o risco, como, de fato, Medvedev havia proposto, de destruir o material literário enquanto o define.

Aqui, a caracterização de Medvedev a respeito de Tynianov é, de novo, completamente destinada às associações anteriores do mesmo/deste. Medvedev tem associado Tynianov explicitamente com a contestação do primeiro conceito formalista sobre matéria, mas ele é incapaz ou relutante em aceitar que isso implica também em uma contestação do outro pilar da teoria do formalismo inicial que observamos brevemente no início, a distinção de uma linguagem especificamente 'poética'. A crítica de Medvedev é que o segundo conceito de matéria de Tynianov, bem como todas as associações problemáticas com as abstrações da linguística, também minam fatalmente a ideia de uma linguagem literária definitiva e distinta. Isso é essencialmente uma repetição da crítica bakhtiniana global do formalismo, no sentido de que os formalistas têm sido consistentemente incapazes, até em seus próprios termos, de conceituar a distinção entre o literário e o que é verbal/textual, mas não-literário ${ }^{69}$ Ainda assim, Tynianov tem estado, no mínimo, desinteressado há muito tempo nesta tarefa; de fato, em relação a seus trabalhos publicados, é possível argumentar que isso nunca foi sua primeira preocupação. Sua apostasia ostensiva do caráter 'ortodoxo' do formalismo é caracterizada por Medvedev como tendo nascido da inconsistência, uma consequência inevitável da premissa inicial problemática do projeto formalista. No entanto, a apostasia de Tynianov não se resulta em sua identificação com o 'outro lado' da moeda da estética material, mas com o estabelecimento 'Marxista' para o qual as manobras políticas de Shklovskii apontam; ${ }^{70}$ nem leva necessariamente a sua associação canônica com a ascensão do estruturalismo, que se apoderou/se aproveitou da resolução proposta por Tynianov e Jakobson do problema da sincronia e diacronia nos termos da evolução sistêmica, mas prestaram pouca ou nenhuma atenção ao conceito subjacente de matéria, o que é o pré-requisito necessário dessa evolução. ${ }^{71}$ Isto leva a sua rejeição dos

68 Iu. N. Tynianov, 'O literaturnoi evoliutsii' [1927], in Poetika. Istoriia literatury. Kino, pp. 270-81; 'On Literary Evolution', in Matejka and Pomorska (eds), Readings in Russian Poetics, pp. 66-78 (hereafter, Tynianov, 'On Literary Evolution').

69 "Sem um conceito sistemático de estética [...] é impossível isolar o objeto da poética - o trabalho verbal artístico - da massa de trabalhos verbais de um tipo diferente': Bakhtin, 'The Problem of Content, Material and Form', p. 261-259.

70 Compare, a esse respeito, as relações mutantes de Shklovskii com Eikhenbaum, o qual foi mais longe em direção a acomodação do Marxismo em seus artigos 'Literatura i pisatel', Zvezda,5, 1927, pp. 121-40, and 'Literaturnyi byt' [1927, as 'Literatura i literaturnyi byt'], in Boris Eikhenbaum, Moi vremennik / Marshrut v bessmertie, Moscou, 2001, pp. 49-59. Shklovskii pôde escrever à Jakobson em Fevereiro de 1929, em sua tentativa de ressurgir com o Opoiaz, que “o 'ambiente literário' [de Eikhenbaum] é o Marxismo mais vulgar. Além disso, ele se tornou ciumento e tem medo de seus próprios estudantes' (citado de Galushkin "” I tak, stavshi na kostiakh...”,, p. 140); e mesmo assim, no fim do ano, Eikhenbaum e Shklovskii co-editaram Slovenost'i kommertsiia. Knizhnaia lavka A. F. Smirdna, Moscou, 2001 [1929], cuja introdução editorial afirma que enquanto 'os autores deste livro não afirmam, em nenhum sentido, que o chamado 'ambiente literário’ (termo de B. M. Eikhenbaum) é a causa primária da evolução literária [...] mas eles consideram que a análise do ambiente literário pode disponibilizar materiais para uma análise das mudanças na função da literatura em diferentes períodos' (pp. 5-6).

71 Tynianov and Jakobson, 'Problems in the Study of Literature and Language', pp. 282- 83; pp. 79-81. 
dois lados da moeda da estética material, e a sua associação, ex post facto como isto devia ser inevitavelmente, a Bakhtin.

A resposta de Tynianov à crise definitiva do Formalismo, que tem sido formulada há muito tempo, foi voltar-se para a ficção histórica (e, em menor escala, à crítica sóbria histórico-literária). ${ }^{72}$

Seja qual for o status do 'Problems in the Study of Literature and Language', sua última declaração ostensiva antes da adoção de um 'silêncio' teórico, a penúltima declaração de Tynianov - e talvez a mais substancial - aponta para uma direção ligeiramente diferente. 'On Literary Revolution', primeiramente publicado anteriormente à tentativa abortiva final de Shklovskii de recuperar uma base institucional segura para a ampla 'escola formal', certamente compartilha da problemática central de 'Problems in the Study of Literature and Language' (e do estruturalismo em geral) em seu exame a respeito da relação entre a série literária e extra-literária (que estão também, e não totalmente fortuito, no cerne das tentativas de aproximação entre formalistas e marxistas). O que tem recebido menos atenção, entretanto, é que Tynianov aqui aborda a questão global do literário frente à frente do não literário ao identificar implicações novas e maravilhosas de sua concepção combinada de matéria. Voltando-se à questão do gênero literário, Tynianov afirma que

A novela, que parece ser um gênero integral que se desenvolveu dentro e de si mesmo
ao longo dos séculos, acaba por não ser um todo integral, mas sim uma variável,
com matéria que varia de um sistema literário para outro, e com métodos variáveis
de introduzir o material do discurso extra-literário na literatura (Tynianov, 'On
Literary Evolution', pp. $274-75 ; p .70){ }^{73}$

Tynianov se volta para a questão de gênero não só porque ela foi 'menos estudada', mas porque ela se oferece como um mecanismo através do qual os efeitos e processos que afetam a 'matéria' podem, literalmente, ser observados: se a concepção de Tynianov de matéria se convenciona com a insistência de Bakhtin na sua condição já 'necessariamente estetizada', gênero é a categoria que nos permite estabelecer precisamente como a realidade é estetizada nas diferentes fases da história da arte verbal:

Como e por quais meios o extra-literário se correlaciona com a literatura? O extra-literário é complexo e multifacetado em sua natureza, e apenas a função de todos seus elementos é específico nele. O extra-literário se correlaciona com a literatura acima de tudo em seu aspecto verbal. [...] Não existem gêneros literários banais. O seu lugar é ocupado pelos fenômenos extra-literários verbais. A função ou orientação verbal busca a forma, e a encontra no romance, na piada, na peça com rima, bouts rimés, charadas, etc. E aqui o aspecto de gênesis, "da presença de certos tipos de forma discursiva extra-literária" (Tynianov, 'On Literary Evolution', pp. 278, 279; pp. 73, 74), adquire sua significação evolutiva.

A segunda parte do livro de Bakhtin sobre Dostoiévski pode suportar os traços de seu engajamento positivo com o formalismo tardio, e seu 'Discourse in the Novel', escrito no

72 Embora vejamos, por exemplo, a carta agonizante de Tynianov para Shklovskii no fim de Março de 1929: 'Estou um pouco perdido, eu não tenho um grande trabalho e receio que perdi o hábito de trabalhar com história e teoria. Mas não tenho intenção nenhuma de me tornar um escritor de novelas' ('Iu. Tynianov to V. Shklovskii, 29 March 1929', Voprosy literatury, 12, 1984, pp. 199-200).

73 O termo russo byt foi traduzido aqui simplesmente como o 'extra-literário' em reconhecimento ao seu significado central neste contexto; alternativas como 'vida doméstica', 'vida cotidiana' ou 'ambiente' trazem conotações adicionais, que desvirtuam de uma compreensão do termo em oposição específica ao 'literário' (assim como a interpretação de Matejka e Pomorska: 'convenções sociais'). 
exílio - portanto, sem empecilhos - no início dos anos 1930, é contundentemente consistente com as formulações de Tynianov em sua abordagem do gênero. ${ }^{74}$ No momento em que 'The Problem of Speech Genres' foi escrito, em 1952-1953, contudo, a tentativa tardia de Bakhtin de desenvolver a proposição inicial de Voloshinov de que "a psicologia social é dada principalmente nas mais variadas formas do 'enunciado', na forma de pequenos gêneros discursivos, internos e externos, que até o presente momento não foram estudados" "75 o status dos artigos teóricos posteriores de Tynianov é manifestado em cada página.

Há mais em jogo, portanto, nesta associação de Bakhtin e o trabalho tardio de Tynianov do que simplesmente lançar um ponto de vista diferente em certas dificuldades locais no ambiente crítico dos soviéticos de 1920, e mais até que a implicação substancial de que ambos (e talvez muitos outros) pertencem a uma 'escola' unificada de teoria literária russa. ${ }^{76}$ Tanto Tynianov como Bakhtin, que trabalham em escolas críticas (e pragmáticas) muito diferentes, sugerem não apenas a possibilidade de renovação do estudo literário, mas o fazem de maneira que isso fique deslumbrantemente integrado e suscetível às problemáticas recorrentes da teoria literária. Em um nível, seu conceito de material literário como indivisivelmente verbal e extra-verbal é a base para um estudo textual sincrônico que é, ao mesmo tempo, imanente $e$ orientado ao contexto extra-literário (mas não, falando adequadamente, extra-verbal) de sua produção. Em outro nível, eles insinuam uma revolução no nosso conceito de gênero literário, visto como um tipo de 'gravador' de evoluções no sistema literário produzidos pelas mudanças na matéria em si, e nas maneiras que ele 'entra' ou 'é trazido para' a literatura: a base que é, para o estudo diacrônico de organização sistêmica e mudança.

Esta metodologia de estudo literário, predicado em uma concepção completamente nova de material literário, não foi acessível a partir da falsa dicotomia e, portanto, reforçando mutuamente a 'estética material' do Formalismo ou do Marxismo: e dada a influência das várias redações do Formalismo e do Marxismo no curso tardio da teoria literária, não é tão surpreendente que ela tenha se mantido inacessível desde então. Ao mesmo tempo,

74 M. M. Bakhtin, 'Slovo v romane', in Voprosy literatury i estetiki. Issledovaniia raznykh let, ed. S. Leibovich, Moscow, 1975, pp. 72-233; 'Discourse in the Novel', in The Dialogic Imagination: Four Essays by M. M. Bakhtin, ed. Michael Holquist, trans. Caryl Emerson and Michael Holquist, Austin, TX, 1981 (hereafter, The Dialogic Imagination), pp. 259-422.

75 Voloshinov, Marxism and the Philosophy of Language, p. 20; p. 232. Bakthin faz uso específico do termo, embora longe de programático, no livro sobre Dostoiévski; em seguida, ele aborda superficialmente uma única vez em seu trabalho entre o fim dos anos 1920 e o início dos anos 1950, na aproximação com 'From the Prehistory of Novelistic Discourse': ver M. M. Bakhtin, muito próximo de 'From the Prehistory of Novelistic Discourse': ver M. M. Bakhtin, 'Iz predystorii romannogo slova', in Voprosy literatury i estetiki. Issledovaniia raznykh let, ed. S. Leibovich, Moscow, 1975, pp. 408-46 (p. 445); 'From the Prehistory of Novelistic Discourse', in The Dialogic Imagination, pp. 41-83 (p. 83). Também, M. M. Bakhtin, 'Problema rechevykh zhanrov', in Sobranie sochinenii.

76 Esta sugestão foi explicitada por Igor Shaitanov em uma conferência em Moscou em 1993 e combinada com o que V. V. Zdol'nikov descreve como 'uma oposição extremamente ativa'; ver Igor Shaitanov, 'Bakhtin i formalisty v prostranstve istoricheskoi poetiki', in M. M. Bakhtin i perspektivy gumanitarnykh nauk, ed. V. L. Makhlin, Vitebsk, 1993, pp. 16-21; Igor' Shaitanov, 'The Concept of the Generic Word: Bakhtin and the Russian Formalists', in Adlam et al. (eds), Face to Face: Bakhtin in Russia and the West, pp. 233-53; see also, V. V. Zdol'nikov, 'Vopros ostaetsia otkrytym (Nemnogo syb" ektivnye zametki o konferentsii “Bakhtin I perspektivy gumanitarnykh nauk”, Moskva, RGGU, fevral' 1993 goda)', Dialog. Karnaval. Khronotop, 1993, 2-3, pp. 198-200. Ver também, D. Kujundzic, Bakhtin i Tynianov kak interpretatory Dostoevskogo', in D.Kujundzic and V. L. Makhlin (eds), Bakhtinskii sbornik II: Bakhtin mezhdu Rossiei i zapadom,Moscow, 1992, pp. 45-49, que enfoca a similaridade nas leituras de Bakhtin e Tynianov do status textual de formas discursivas variadas em Dostoiévski, sem explicitar a relação entre esta problemática e o problema da matéria, a qual, em nossa perspectiva, é inseparável. 


\section{Conexão Letras}

é irônico e apropriado que a reorientação de Tynianov sobre o formalismo, conduzido por uma percepção da necessidade de historicizar a teoria, deva ser apresentada como um movimento a partir do qual a história da teoria requer que seja reescrita; é ainda mais apropriado que este imperativo histórico seja intrinsecamente ligado aos imperativos de renovação nos termos que podemos hesitar em caracterizar como 'meramente' literário ou 'puramente' teórico.

Tradução: Fabiana Ribeiro do Nascimento, Ana Zandwais Revisão: Maria Inês Batista Campos, Nathalia R.S. Polachini

\section{Referências}

ADLAM, Carol et al. (eds.) Face to face: Bakhtin in Russia and the west. Sheffield, 1997. ARVATOV, B. Literatura i byt. In: Zvezda, nº 6, 1925, p. 308-319.

BAKHTIN, M.M. Problema soderzhaniia, materiala i formy v slovesnom khudozhestvennom tvorchestve. In Raboty 1920-kh godov, Kiev, 1994, p. 257-318; ‘

. The Problem of Content, Material and Form in Verbal Art', in Art and Answerability: Early Philosophical Essays by M. M. Bakhtin. Ed.. Michael Holquist and Vadim Liapunov; trans. Vadim Liapunov and Kenneth Brostrom, Austin, Texas Press University, 1990, p.257-325.

. Problemy tvorchestva/poetiki dostoevskogo. Kiev, 1994.

Discourse in the Novel', in The Dialogic Imagination: Four Essays by M. M. Bakhtin, ed. Michael Holquist, trans. Caryl Emerson and Michael Holquist, Austin, TX, 1981

BERNARD-DONALS, Michael. .Mikhail Bakhtin: Between Phenomenology and Marxism, Cambridge, 1994.

BOCHAROV, S.G., NIKOLAIEV, N.I. Sobranie sochinenu. Moscow, 2003, vol1, p.707-41 BRANDIST, Craig. The Bakhtin Circle: philosophy, Culture, politics. London, London and Sreling, 2002.

BRIK, Osip. The so called formal method. Russian poetics in translation, 4, 1977.

EIKHENBAUM, Boris. Moi vremennik / Marshrut v bessmertie, Moscou, 2001, ERLICH, Viktor. Russian formalism History. The Hague: Ed. Doctrine, 1980 .

MARX, Karl. Selected writings. Oxford, Ed. David Mc. Lellan, 1977

MATEJKA, Ladislav. 'Deconstructing Bakhtin in C.A. Mihailescu e W. Hamarneh (eds), Fiction Updated: Theories of Fictionality, Narratology and Poetics, Toronto, 1996, pp. 257-66

, POMORSKA Krystyna (eds), Readings in Russian Poetics: Formalist and Structuralist Views, Ann Arbor, MI, 1978

MEDVEDEV, P.N. Formal nyi metod v literaturovedenu kriticheskoe v sotsiologicheskuiu poetiku. Leningrad, 1928

. Formalizm i formalisty, Leningrad, 1934,

.BAKHTIN, M.M. The formal method in literary scholarship: a critical introduction to sociological poetics. Baltimore, MD, 1978. Trans. Albert Wehrle.

PLEKHANOV, G.V. Literatura I estetika. Moscow, 1958.

SHAITANOV, Igor. 'The Concept of the Generic Word: Bakhtin and the Russian 
Formalists', in ADLAM, Carol et al. (eds). Face to Face: Bakhtin in Russia and the west. Sheffield, 1997.

SHKLOVSKII, V. B. Kak sdelan Don Kikhof. In: SHKLOVSKII, V.B. O teory prozy. Moscow, p.91-124.

SHUKMAN, Ann 'Between Marxism and Formalism: the Stylistics of Mikhail Bakhtin', in Elinor Shaffer (ed.), Comparative Criticism: A Yearbook, 2, 1980, p. 221-34;

TIHANOV, Galin. Zametki o dispute formalistov i marksistov 1927 goda', Novoe literaturnoe obozrenie, 50, 2001.

TYNIANOV, Iurii. O literaturnon fakte. Lef,2, 1924, p.101-116.

, JAKOBSON, Roman. Problemy izuichenua literatury i yazika In: TYNIANOV, I.

Poetika. Istoriia literatury. Moscow, Kino, 1977. . The fundamentals of cinema. Russian poetics in translation. 1982, p.32-54

TROTSKII, L .Literature and Revolution, London, 1991.

USTINOV, D. Materialy disputa "Marksizm i formal'nyi metod" 6 marta 1927, Novoe literaturnoe obozrenie, 2001.

SHAFFER, Elinor (ed.), Comparative Criticism: A Yearbook, 2, 1980, p. 221-34

SHOR, R. Formal nyi metod na zapade. Ars. Poetica. Moscow: Ed. M.A. Petrovskii, 1927 VOLOSHINOV, V. Marxism and the philosophy of language. Cambridge, London, 1991. . Marksizm i filosofiia iazyka. In: VOLOSHINOV, V. Filosofiia i sotsiologiia gumanitarnykh nauk. Sao Petersburg, 1995, p. 216-380.

ZHIRMUNSKII, V. M. Theoriia literatury. Poetika stilistika. Leningrado, 1977, p.15-55 . Theoriia literatury. Poetika. Stilistika. Leningrado, 1977, 